\title{
Characterization of oestrogen receptors in zebrafish (Danio rerio)
}

\author{
P-L Bardet, B Horard, M Robinson-Rechavi, V Laudet and J-M Vanacker \\ Laboratoire de Biologie Moléculaire et Cellulaire, CNRS UMR 5665, Ecole Normale Supérieure de Lyon, 46 allée d'Italie, 69364 Lyon, France \\ (Requests for offprints should be addressed to J-M Vanacker; Email: jean-marc.vanacker@ens-lyon.fr)
}

\begin{abstract}
We cloned the cDNAs corresponding to three oestrogen receptors (ERs) in zebrafish (Danio rerio). Sequence analysis and phylogenetic studies demonstrated that two of these genes, ER $\beta .1$ and ER $\beta .2$, arose from duplication of the original ER $\beta$ in many species of the fish phylum, whereas $E R \alpha$ is unique. Zebrafish ERs behaved as oestrogen-dependent transcription factors in transactivation assays. However, their reactivity to various oestrogen modulators was different compared with that of mouse ERs. ER mRNA expression during zebrafish development is restricted to distinct time periods, as observed by RNase protection assays. ER $\beta .2$ is initially expressed as maternally transmitted RNA, until $6 \mathrm{~h}$ after fertilization, when expression disappears. Between 6 and $48 \mathrm{~h}$ after fertilization, no ER expression could be observed. After $48 \mathrm{~h}$ after fertilization, all ERs, but predominantly ER $\alpha$, began to be expressed. We conclude that oestrogen signal transduction can operate during zebrafish development only within discrete time windows.
\end{abstract}

Journal of Molecular Endocrinology (2002) 28, 153-163

\section{Introduction}

Over the past 10 years, zebrafish (Danio rerio) has received growing attention as an alternative animal model that is particularly suitable for the study of embryonic development, mostly in its early phases. In addition, zebrafish is also being used as an in vivo model for the identification of small molecules that can interfere with normal developmental (Peterson et al. 2000) or physiological processes, including the detection of water pollutants and endocrine disruptors. To the latter class of compounds belong molecules that interfere with reproductive functions and mimick or antagonize the effects of endogenous hormones such as oestrogens. A growing number of so-called xeno-oestrogens, present in food or the environment, have been identified that jeopardize the reproductive capacities of various animals, including humans. Adequate transmission of the signal conveyed by oestrogen is indeed necessary for reproduction. This is illustrated by the fact that mice lacking the aromatase gene (the key enzyme for oestrogen production in vivo) or oestrogen receptors (ERs) are sterile or exhibit reduced fertility (Fisher et al. 1998, Couse \& Korach 1999, Couse et al. 1999, Dupont et al. 2000).

Oestrogens are small lipophilic molecules that cross the cell membrane and are bound by specific nuclear receptors. ERs act as ligand-dependent transcription factors that regulate the expression of their target genes either by binding to specific sequences (the oestrogen response elements, ERE) or by interfering with other transcription factors such as Spl or the AP1 complex (Paech et al. 1997, Saville et al. 2000, reviewed in Hall et al. 2001). In mammals, two oestrogen receptors have been identified: ER $\alpha$ (Green et al. 1986) and ER $\beta$ (Kuiper et al. 1996) (official names NR3Al and NR3A2 respectively). The ERs display both overlapping and distinct ligand-binding capacities (Kuiper et al. 1997), patterns of expression during development (Lemmen et al. 1999) and in the adult (Couse \& Korach 1999), transcriptional properties (Paech et al. 1997, Vanacker et al. 1999, Saville et al. 2000), and knockout phenotypes (Lubahn et al. 
1993, Krege et al. 1998, reviewed in Couse \& Korach 1999). In addition, mouse (m) ERs have been suspected to have opposite physiological roles in some tissues such as the uterus and the prostate (Weihua et al. 2000, 2001).

Oestrogen receptors are organized in modular domains, two of which have been particularly conserved during evolution: the DNA-binding domain (DBD), and the ligand-binding domain (LBD), which also mediates coactivator binding, dimerization and ligand-dependent transactivation through the activation function 2 (AF2) region (for reviews see Gronemeyer \& Laudet 1995, Mangelsdorf et al. 1995). Human and trout $\mathrm{ER} \alpha$, for instance, share 90\% sequence identity in their DBD (Pakdel et al. 1989). Conversely, ER $\alpha$ and $\mathrm{ER} \beta$ are also highly related, as sequence comparison between orthologues indicates more than 90\% sequence identity in the DBD and 65\% in the LBD (Kuiper et al. 1996, Laudet 1997). Another activation function (AF1) that mediates ligand-independent transactivation resides in the N-terminal part of the protein and is poorly conserved between receptors and between species.

In an effort to determine the conditions under which zebrafish can be used as a model for the detection of molecules interfering with oestrogen signalling, we have characterized the oestrogen receptors in this species. We herein report the isolation of three ERs in zebrafish, two of which (ER $\beta .1$ and ER $\beta .2$ ) have arisen after specific duplication of the $E R \beta$ gene in part or all of the fish phylum. In common with their mammalian counterparts, all three zebrafish receptors can be transcriptionally activated by $17 \beta$-oestradiol $\left(\mathrm{E}_{2}\right)$. However, other molecules activating all or some of the mERs, such as $4 \mathrm{OH}-\mathrm{E}_{2}$ and $4 \mathrm{OH}-$ tamoxifen, are inactive toward the zebrafish (zf) ERs. This suggests that the spectrum of molecules activating the ERs is different between mouse and zebrafish. During development of the zebrafish, ER $\beta 2$ is expressed in a maternally inherited manner. After the onset of zygotic transcription, no ER expression could be detected until $48 \mathrm{~h}$ post fertilization, when all ERs, but predominantly $\mathrm{ER} \alpha$, start to be detected in a diffuse manner. Our results suggest that oestrogenic signalling could only be efficiently transduced during very early development and in later embryonic phases.

\section{Material and methods}

\section{Molecular cloning}

One microgram of total RNA pooled from male and female adult zebrafish was retrotranscribed using Moloney murine leukaemia virus reverse transcriptase (Gibco Brl) and submitted to nested PCR using degenerated primers located in the conserved DBD and LBD. PCR products were cloned into pCR2.1 vector (Invitrogen) and individual clones were sequenced. An expressed sequence tag (EST) was also found in Genbank (access number AW134052) corresponding to a zfER (ER $\beta 2$ ). The corresponding clone (2601181; Incyte Genomics Inc., Palo Alto, CA, USA) was ordered and sequenced. Before transfection experiments, cDNAs were cloned in the blunted EcoRI site of pCMX plasmid.

Rapid amplification of cDNA ends (RACE) experiments were performed using the $5^{\prime} / 3^{\prime} \mathrm{RACE}$ kit (Roche) and following the manufacturer's instructions.

Degenerate oligonucleotides used were:

ER 5'4: (A/G)GIAA(A/G)AG(C/T)TG(C/T)

GA(G/A)GGITG

ER 5'5: A(C/T)GAAGTIGGIATG(A/G)

TGAAAG

ER 5'6: T(C/T)GAAGT(A/G)GG(A/G)ATG

(A/G)T(G/G)AAGT

ER 3'1: GIIGTIG(T/C) CA(G/G)IA(G/A)

CATGTC

ER 3'2: CAITTICG(T/G)T(G/C)(A/G)(T/C)

(T/C)CGTGTCGA

\section{Phylogenetic analysis}

Protein sequences were aligned automatically by Clustal W (Thomson et al. 1994) with manual correction in Seaview (Galtier et al. 1996). Trees were constructed by neighbour-joining (Saitou \& Nei 1987), with Poisson-corrected distance in amino acid sequences of only the well-conserved DBD and LBD domains, implemented in Phylo_ win (Galtier et al. 1996). Support for branches in the tree was investigated by bootstrap (Felsenstein 1985), with 1000 replicates.

\section{Cells and transfections}

Rat osteosarcoma ROS 17/2.8 cells were maintained in DMEM supplemented with 10\% fetal calf 
serum (FCS). Before transfections, cells were cultivated for 2 weeks in phenol-red-free DMEM supplemented with $10 \%$ charcoal-treated FCS, to ensure steroid clearance. For transient transfections, $10^{5}$ cells were seeded in 24-well plates and transfected using $3 \mu \mathrm{l}$ ExGen 500 (Euromedex, Souffelweyersheim, France), 50 ng reporter plasmid and $50 \mathrm{ng}$ ER-encoding plasmid. pCMX plasmid was added as a carrier up to $500 \mathrm{ng}$. After $5 \mathrm{~h}$, cells were supplemented with fresh medium to which $10^{-8} \mathrm{M}$ hormone was added as needed. Cells were lysed $48 \mathrm{~h}$ after transfection and reporter activity was determined, using standard methods. All transfections were performed in triplicate.

\section{RNase protection assays}

For total RNA extraction, 200-400 embryos were scraped in $3 \mathrm{ml} 4 \mathrm{M}$ guanidinium thiocyanate solution. RNA was extracted by phenol/ chloroform, precipitated by isopropanol and resuspended in RNase-free water. Antisense RNA probes were prepared by in vitro transcription of linearized templates with T7 (MAXIscript, in vitro transcription kit, Ambion) or T3 (Promega) RNA polymerase using phosphorus-32-labelled UTP. After phenol/chloroform extraction and precipitation, probes were hybridized with $15 \mu \mathrm{g}$ of each stage RNA and digested with RNase A/T1 (RPAIII kit, Ambion). Samples were separated on a 5\% denaturing polyacrylamide gel, dried, analysed by PhosphorImager (Amersham Pharmacia) and quantified using ImageQuant software (Amersham Pharmacia).

\section{Results}

\section{Identification of ERs in zebrafish}

To isolate ER cDNAs, we first performed RT-PGR using total RNA extracted from pooled male and female adult zebrafish. Degenerated primers located in conserved regions (DBD and LBD) were designed to amplify both $\mathrm{ER} \alpha$ and $\mathrm{ER} \beta$. These experiments gave rise to three distinct species of the expected size. $5^{\prime}$ and $3^{\prime}$ RACE were then performed to produce complete cDNAs that were subsequently sequenced. One of the PCR fragments was also present in a zebrafish EST (accession number AW134052). Open reading frames in the cDNAs were predicted to produce putative proteins of 570, 558 and 554 amino acids (ER $\alpha, \quad \mathrm{ER} \beta .1$ and $\mathrm{ER} \beta .2$ respectively). The predicted sequences were then aligned with $\mathrm{mER} \alpha$ and $\operatorname{mER} \beta$ (Fig. 1). The zfER cDNAs bore the typical DBD of nuclear receptors organized in two zinc-finger modules and LBD located in the C-terminal part of the protein. As expected, sequence identity within these domains is increased between species (over 95\% for the DBD, close to $70 \%$ for the LBD when comparing mouse and zfER).

Using the neighbour-joining method, we then analysed the phylogenetic relationships of zfERs to oestrogen receptors previously cloned in other species, in particular in various fish (Fig. 2). All $\mathrm{ER} \alpha$ were homogenously grouped within a single group. In contrast, fish ER $\beta$ proteins appeared to be clustered in two distinct groups, equally related to mammalian ER $\beta$. Furthermore, in some species such as zebrafish, goldfish (Carassius auratus) or atlantic croaker (Micropogonias undulatus), two different $\operatorname{ER} \beta$ proteins have been identified, one from each group. This indicates that the ER $\beta$ gene has undergone duplication in an ancestor common to various teleosts, after the emergence of the fish phylum from the remainder of the vertebrates. In agreement with current nomenclature procedure, we hereafter refer to zebrafish ER $\beta$ s as $\operatorname{ER} \beta .1$ and ER $\beta .2$ (official nomenclature: NR3A2-A and NR3A2-B, respectively).

\section{Transcriptional activities of zfERs}

ERs activate transcription in an oestrogendependent manner through a variety of response sites, the most typical of which is composed of two head-to-head AGGTCA half sites separated by three nucleotides (hereafter referred to as the ERE). To analyse the transcriptional properties of the zfERs, we cotransfected a reporter plasmid containing two EREs in front of a minimal th promoter driving the luciferase reporter gene (EREtkLuc), together with a zfER encoding plasmid (Fig. 3). mERs were used as controls. In the absence of exogenously added oestrogen, no significant ER-driven transactivation could be detected. In contrast, all ERs activated the expression of the luciferase reporter gene in the presence of $\mathrm{E}_{2}\left(10^{-8} \mathrm{M}\right)$, the natural ligand of mammalian ERs. We also analysed the effects of other natural or synthetic oestrogenic agents 
DNA binding domain

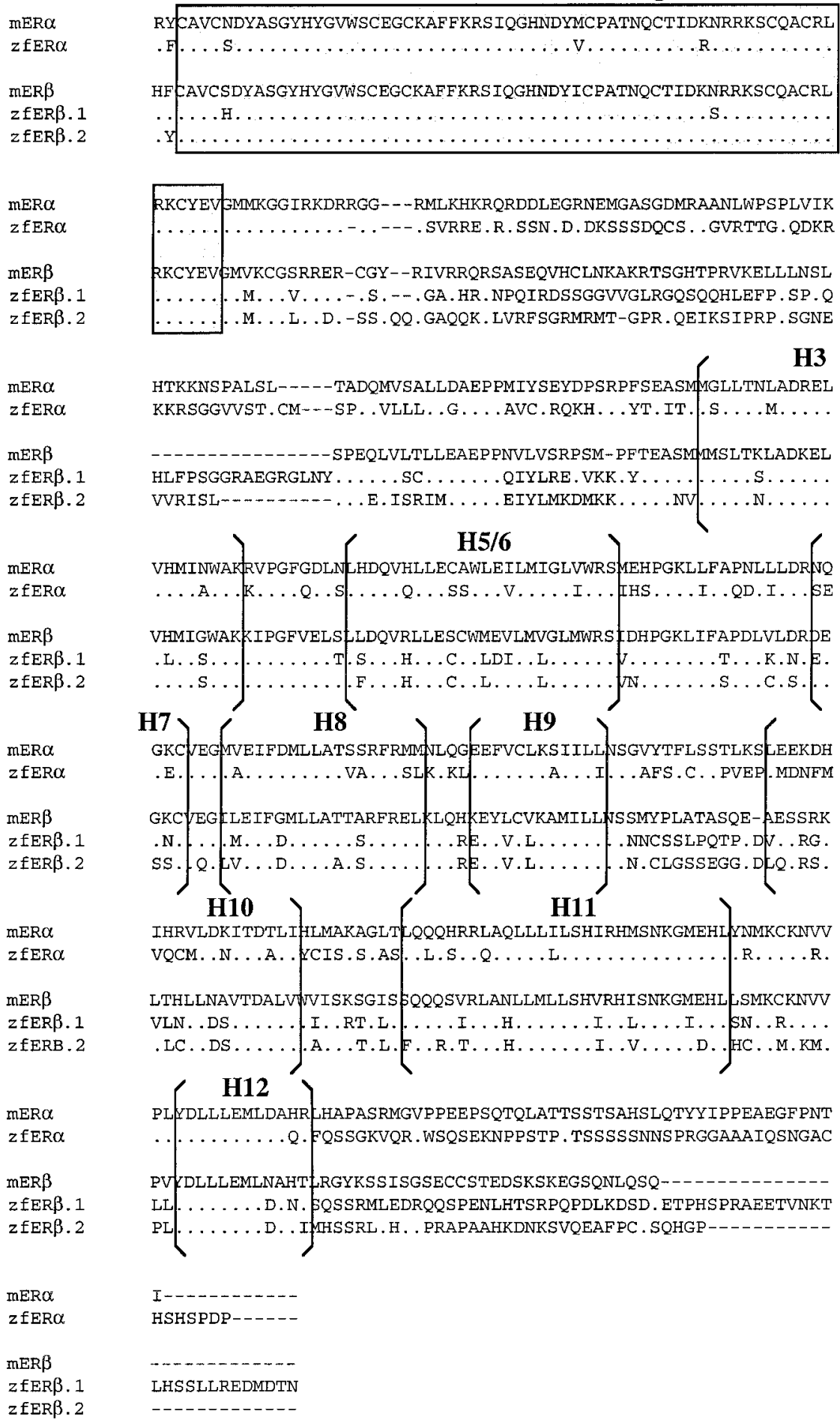

Figure 1 Alignment of mouse and zebrafish ER sequences. Mouse and zebrafish sequences were aligned using Clustal W with Seaview manual corrections. A dot represents identical amino acids using mouse sequence as a reference, whereas a dash symbolizes a gap. The DNA binding domain is boxed and the major helices $(\mathrm{H})$ within the ligand binding domain appear within brackets. 


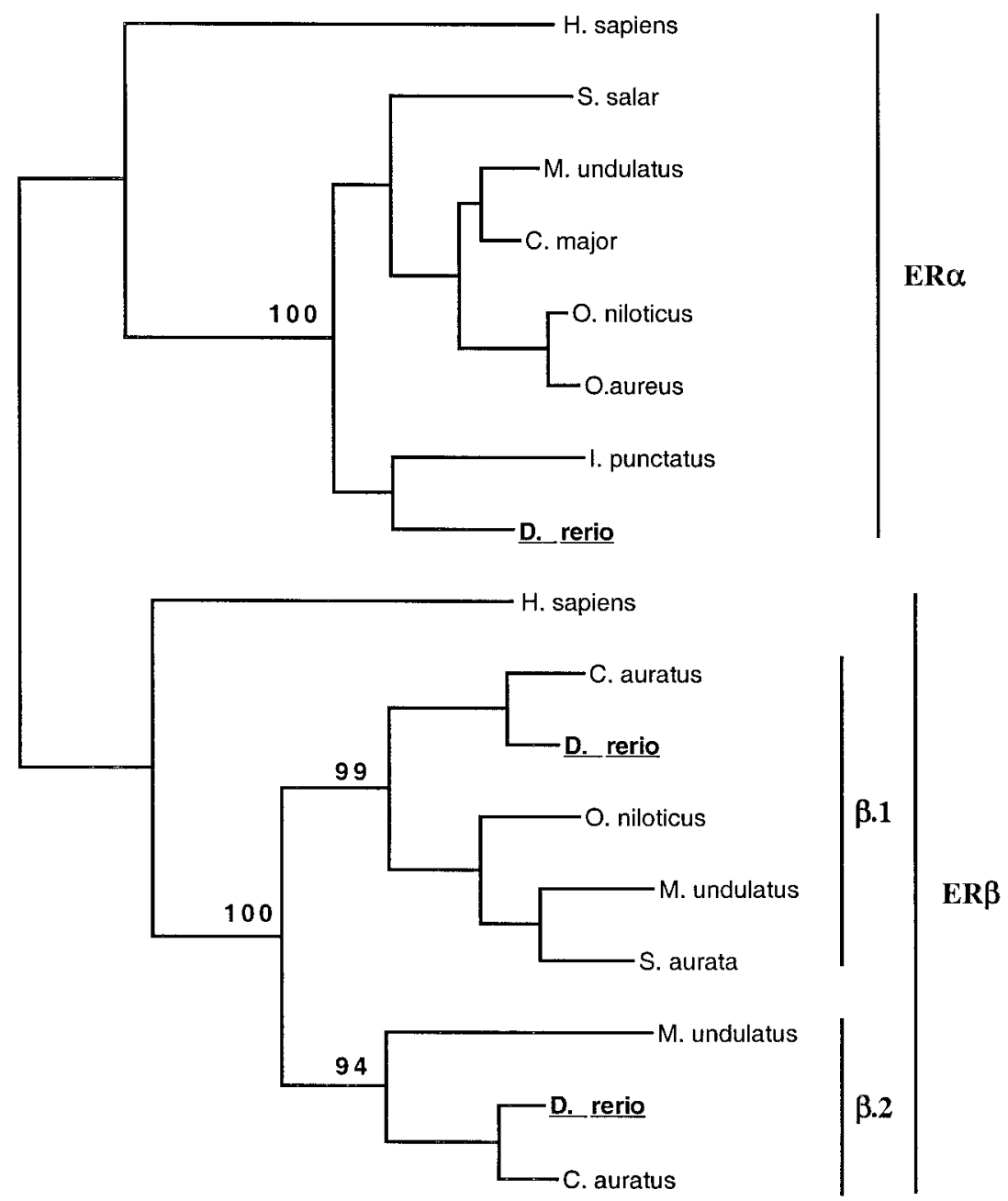

Figure 2 Phylogenetic tree of ERs. The tree was built using the neighbour-joining method, using 318 sites with global gap removal and performing 1000 bootstrap replicates. All bootstrap values were more than $90 \%$. Only those bootstrap values that support grouping of all ER $\alpha$ genes, and clustering of ER $\beta$ ones in two subgroups, are shown. The Genbank accession numbers of the sequences used in the tree are: Sparus aurata (gilthead seabream): AF136980; Micropogonias undulatus (atlantic croaker): AF298183, AF298181, AF298182 (ERo, ERß.1 and ER 3.2 respectively); Carassius auratus (goldfish): AF061269, AF177465 (ER $\beta .1$ and ER $\beta .2$ respectively); Ictalurus punctatus (channel catfish): AF061275; Chrysophrys major (red seabream): AB007453; Oreochromis niloticus (Nile tilapia): U75604, U75605 (ER $\alpha$ and ER $\beta$ respectively); Salmo salar (salmon): X89959; Oreochromis aureus (blue tilapia): X93557; Homo sapiens (human): $\mathrm{M} 12674, \mathrm{AF} 051427$ (ER $\alpha$ and $\mathrm{ER} \beta$ respectively).

$\left(10^{-8} \mathrm{M}\right)$. The same levels of activation were achieved by diethylstilbestrol, regardless of the ER used. In contrast, $4 \mathrm{OH}-\mathrm{E}_{2}$, although acting as an activator of mERs, surprisingly had no effect on any of the zfERs. 4OH-Tamoxifen - a selective oestrogen receptor modulator - activated $\mathrm{mER} \alpha$ but not mER $\beta$, as already reported (Tremblay et al. 1997, Watanabe et al. 1997). However, tamoxifen was also unable to activate any of the zfERs. Lack of transactivation was also observed with $10^{-7} \mathrm{M} 4 \mathrm{OH}-\mathrm{E}_{2}$ or tamoxifen (data not shown). The observed transactivations are due to 


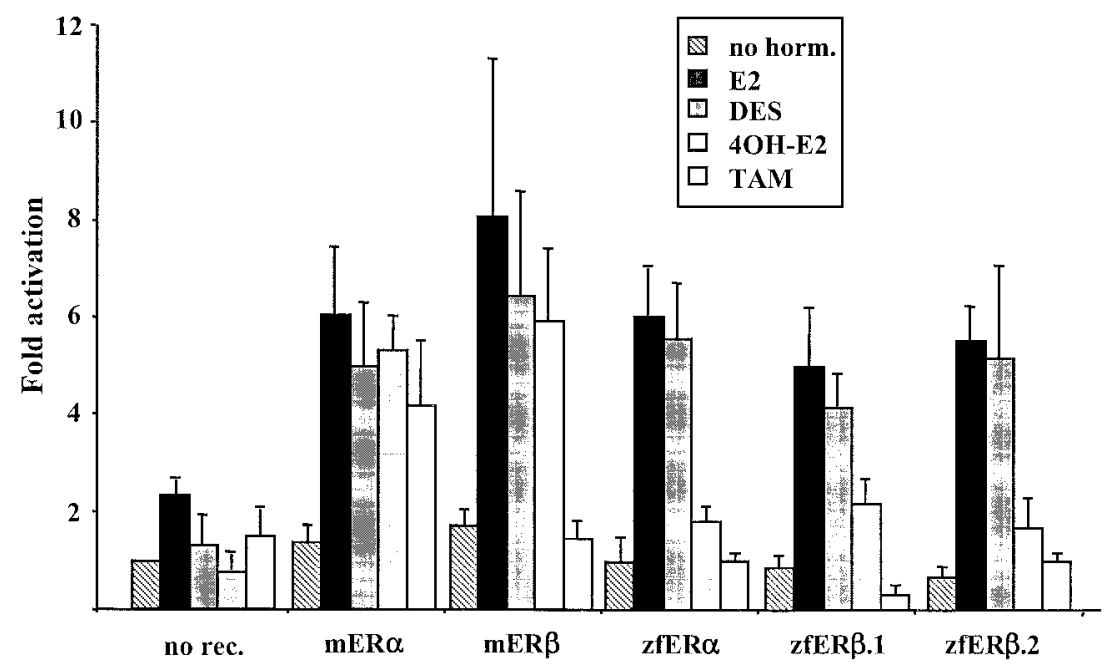

Figure 3 Transcriptional activities of the ERs. Rat osteosarcoma ROS17/2.8 cells were transiently cotransfected with $50 \mathrm{ng}$ EREtkLuc reporter together with $50 \mathrm{ng}$ ER-encoding plasmid, as indicated. Culture medium was supplemented with $10^{-8} \mathrm{M}$ hormone (horm.) where indicated. Values are expressed as fold activation (and standard deviations) over the reporter transfected without ER and without hormone. E2, oestradiol; DES, diethylstilbestrol; TAM, tamoxifen.

the exogenously derived receptors, because the EREtkLuc, transfected alone, reacted only weakly to hormone treatment, suggesting that our cells only weakly express endogenous ERs. Our results indicate that the capacity of a given compound to activate the oestrogen receptor transcriptionally differs between zebrafish and mammals. This also suggests that it might not be appropriate to extrapolate an oestrogenic response from one species to another.

\section{Expression of ERs during zebrafish development}

As a next step in characterizing the zfERs, we attempted to determine the features of their expression during development. This was initially performed by in situ hybridization experiments in whole embryos. However, none of the zfERs displayed a discrete pattern of expression, at least during the first 4 days after fertilization. Indeed, ER $\beta .1$ was expressed in a diffuse manner at a very low level throughout development, whereas ER $\alpha$ was undetectable using this procedure (data not shown). Therefore, we chose to use RNase protection assays (RPA) using RNAs extracted from pooled whole embryos at different stages of development. This has the advantage of enhancing potential signals and still provides temporal, though not spatial, information.

During early development $(1-6 \mathrm{~h}$ after fertilization), only ER $\beta .2$ was detected (Fig. 4), indicating that the expression of this gene is maternally inherited. Zygotic transition (begining of embryonic transcription) indeed only occurs around $4 \mathrm{~h}$ after fertilization. This is illustrated by the control of elongation factor 1 (EF1), also a maternally transmitted RNA, expression of which was dramatically enhanced at $6 \mathrm{~h}$ after fertilization (Delaunay et al. 2000). In contrast, expression of ER $\beta .2$ was stable until this time of development and then collapsed between 6 and $12 \mathrm{~h}$ after fertilization. During the subsequent phases of development, ER expression was initially very low, and became augmented with time (Fig. 5). For instance, signals corresponding to ER $\alpha$ were very weak between 12 and $48 \mathrm{~h}$ after fertilization and underwent a dramatic enhancement around $72 \mathrm{~h}$ after fertilization. Though to a lesser extent, this was also true for $\operatorname{ER} \beta .1$ and $\operatorname{ER} \beta .2$, the corresponding signals for which were barely detectable before $48 \mathrm{~h}$ after fertilization. As a control, EF1 expression is stable during these phases of development. We conclude that ER 
$\mathbf{A}$

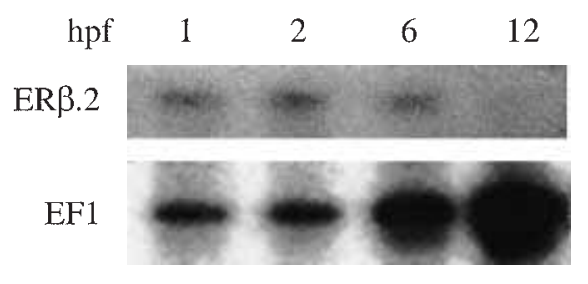

B

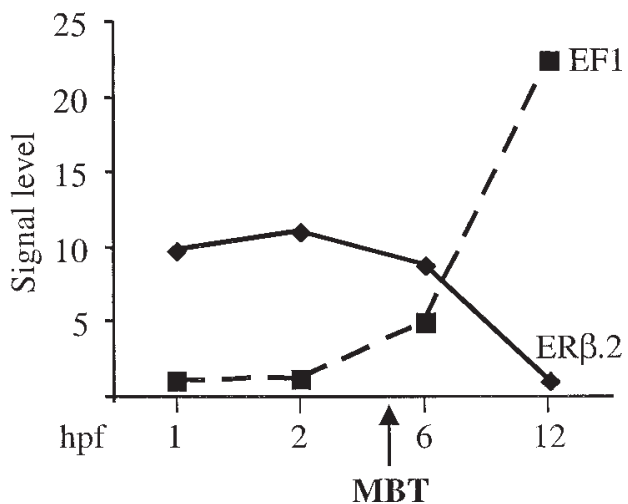

Figure 4 Early embryonic expression of zebrafish ER 3.2 . (A) RNase protection assays. RNAs extracted at the indicated times after fertilization were protected by ER $\beta .2$ and the corresponding EF1 probe. Different exposure times were used. (B) Quantification. Results are expressed relative to the amount of EF1 signal at $1 \mathrm{~h}$ after fertilization. The time of midblastula transition (MBT), when embryonic transcription starts, is indicated. hpf, hours post fertilization.

genes are poorly expressed during the early phases of zebrafish development, and suggest that they might not be necessary to these processes.

\section{Discussion}

In this paper, we describe the initial characterization of oestrogen receptors in the zebrafish (Danio rerio). Our work documents the existence of three ERs in this species, resulting from a duplication of the $E R \beta$ gene. We also show that the zfERs can react to oestrogen agonists in a different way as compared with their mammalian orthologues. Finally, we demonstrate three phases in the embryonic expression of ER.

\section{Three ERs in zebrafish}

Our phylogenetic analysis of ER proteins from fish and other vertebrates, including human, strongly supports two conclusions. First, the zebrafish ER $\alpha$ we have isolated is the orthologue of the human $\mathrm{ER} \alpha$. The characterization of only one $\mathrm{ER} \alpha$ in each fish studied, with an ER $\alpha$ phylogeny reflecting that of the species, supports the experimental data in demonstrating that there is no second ER $\alpha$ in fish. Second, the other two ERs characterized in the zebrafish group had fish ER $\beta$ sequences, indicating that they represent a fish-specific duplication of $E R \beta$. This is further supported by the grouping of various fish $\operatorname{ER} \beta$ proteins with each zfER $\beta$, including one of each ER for fish in which two ER $\beta$ proteins have also been reported (Hawkins et al. 2000). Thus it appears that the two other fish ERs should be named ER $\beta .1$ and ER $\beta .2$, and not $\operatorname{ER} \beta$ and $\operatorname{ER} \gamma$ (Hawkins et al. 2000). Although their origin is debated (Amores et al. 1998, Robinson-Rechavi et al. 2001b), there is increasing evidence that duplicate genes are much more frequent in fish than in mammals (RobinsonRechavi et al. 2001a). Thus there are, in zebrafish, three ERs instead of two, because $E R \beta$ is duplicated in euteleost fish.

\section{ER differential transactivating properties}

Oestrogens have been implicated either positively or negatively in a variety of diseases such as breast cancer and osteoporosis. This has led to the design of various molecules as therapeutic agents, now collectively referred to as selective oestrogen 
A

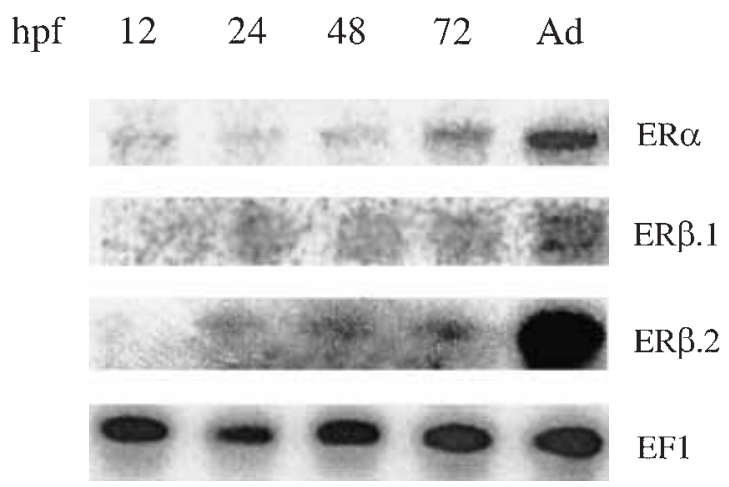

B

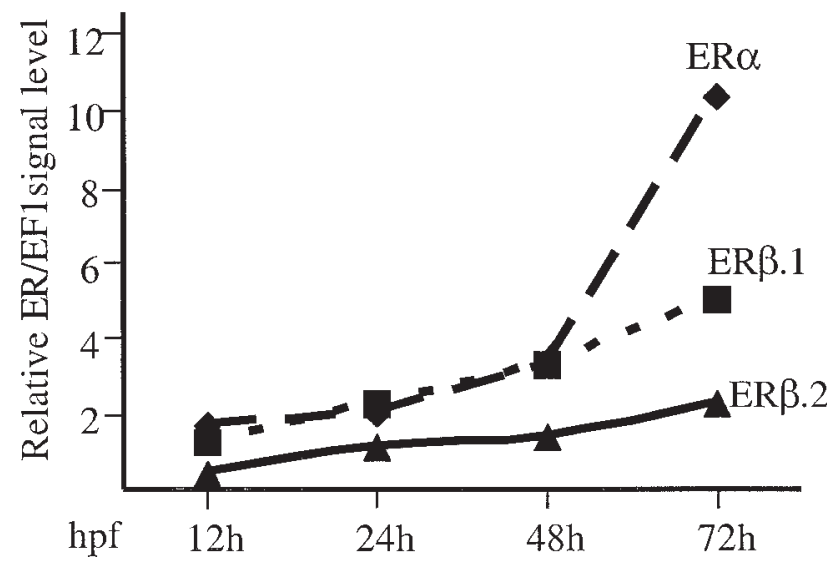

Figure 5 Late embryonic expression of zfERs. (A) RNase protection assays. RNAs extracted at the indicated times after fertilization were protected by ER and the corresponding EF1 probe. RNAs extracted from adult zebrafish (Ad) were used as a control. Different exposure times were used. Note that the ER $\beta .1$ signal appears as two bands, which could represent alternative splice versions of the gene or, alternatively, could be due to persistent secondary structures. (B) Quantification. ER signals were plotted relative to the EF1 signal in each sample. hpf, hours post fertilization.

receptor modulators (SERMs), which display either agonistic or antagonistic activities according to the receptor, tissue/cell system and promoter concerned (reviewed in McDonnell 1999). Because of the ease of breeding, zebrafish may be presumed to be a convenient model for the in vivo evaluation of molecules that could affect development or physiology. As these molecules mostly act through the ERs, it was important to characterize the reactivity of the zfERs to some of these molecules, and to compare it with that observed for mammalian receptors.

All ERs tested have a comparable $\mathrm{E}_{2}$ transcriptional response. This is also true for diethylstilboestrol, a synthetic oestrogen that has been widely used to prevent spontaneous abortions. In contrast, zfERs are not stimulated by $4 \mathrm{OH}-\mathrm{E}_{2}$, a catecholoestrogen, although this compound fully activates both mERs (Kuiper et al. 1997, our present results). This difference between mouse and zebrafish cannot be explained by sequence divergence in the ligand-binding pocket itself (as determined through crystallographic studies by Brzozowski et al. 1997), because all amino acids constituting it, including those in contact with the ligand, are conserved between zebrafish and mouse. However, it is still possible that $4 \mathrm{OH}-\mathrm{E}_{2}$ requires other amino acids for efficient binding. Alternatively, $4 \mathrm{OH}-\mathrm{E}_{2}$ may bind to zfERs but generate a receptor conformation different from that generated by $\mathrm{E}_{2}$, and which is not recognized by the mammalian coactivators present in our cultured cells. 4OHTamoxifen is a SERM used in the treatment of breast cancer and osteoporosis (reviewed in Avioli 1999, Jordan \& Morrow 1999) that activates ER $\alpha$ but not ER $\beta$ (Tremblay et al. 1997, Watanabe et al. 1997). It has been suggested that this compound requires both $\mathrm{AF} 1$ (the presence of which on $\mathrm{ER} \beta$ is still questioned) and AF2 functions for full activation. The fact that the $\mathrm{A} / \mathrm{B}$ domain where the $\mathrm{AF} 1$ function resides is not conserved between zebrafish and mouse ERs provides a likely explanation for the lack of activation capacity of 4OH-tamoxifen on zfERs.

Our results therefore show that zfERs behave in the same way as their mammalian counterparts for some oestrogenic ligands, and very differently for others. 


\section{Three phases of ER expression during zebrafish development}

ERs are weakly expressed during zebrafish development and did not yield a discrete pattern of expression observable by in situ hybridization of whole embryos. However, three phases can be distinguished in ER expression. During the first, ER $\beta .2$ is uniquely expressed in a maternally transmitted manner. The second is characterized by a near absence of ER expression. In the third, starting between 48 and $72 \mathrm{~h}$ after fertilization, all ERs, but predominantly $\mathrm{ER} \alpha$, begin to be expressed. During mouse embryonic development, $\mathrm{ER} \alpha$ has been detected by RT-PGR in fertilized eggs and at the blastocyst stage (Hou \& Gorski 1993). As detected by in situ hybridization techniques, ERs appear to be expressed relatively late, starting with ER $\alpha$ at E9.5 in the heart atrium (Lemmen et al. 1999). In mammals, there are no reports indicating a maternally inherited expression of $\operatorname{ER} \beta$, which could thus be specific to only one of the duplicated genes present in fish. The absence of ERs during long periods of development in zebrafish also suggests that ERs are not required for development. In agreement with this, mice knockouts for one or both $E R$ genes survive throughout development, although multiple defects are reported that mainly affect reproductive functions (Lubahn et al. 1993, Krege et al. 1998, reviewed in Couse \& Korach 1999, Couse et al. 1999, Dupont et al. 2000).

Our expression data suggest that $\mathrm{E}_{2}$ signalling might be efficiently transduced in a time-dependent manner - that is, only when an ER is expressed. As no embryonic transcription is believed to take place before $4 \mathrm{~h}$ after fertilization (the onset of zygotic transition), ER $\beta .2$, as the unique ER isotype expressed, could transmit an oestrogen signal from $4 \mathrm{~h}$ after fertilization to 8-12 h after fertilization, after which time no ER expression can be detected. However, this requires the presence of a ligand produced by the embryo during this period. In this respect, it has recently been reported that an isotype of the aromatase gene (cyp19 - the key enzyme in oestrogen production) is also expressed in zebrafish in a maternally inherited manner (Kishida \& Callard 2001), which renders likely the in situ production of oestrogen before $12 \mathrm{~h}$ after fertilization. Aromatase expression becomes undetectable at $12 \mathrm{~h}$ after fertilization and remains absent until $48 \mathrm{~h}$ after fertilization, when both isotypes begin to be expressed. This time point corresponds to the onset of ER embryonic expression. It is therefore likely that the zebrafish embryo produces both ligand and receptor within the same window of time, provided that a source of androgens, the substrate of aromatase, exists. Ligand and receptor production are likely to be coordinated, as both aromatase and ER $\alpha$ expression have been reported to be under the control of oestrogens (Berkenstam et al. 1989, Pakdel et al. 1989). Indeed, $\mathrm{E}_{2}$ treatment of zebrafish embryos results in an increase in aromatase expression (Kishida \& Callard 2001). However, this stimulation could be visualized only at $48 \mathrm{~h}$ after fertilization, even when $\mathrm{E}_{2}$ was supplemented as early as $2 \mathrm{~h}$ after fertilization. This suggests that the embryo is unable to transduce oestrogen signalling before $48 \mathrm{~h}$ after fertilization, which is in agreement with the absence of ER expression reported in the present paper. This is further illustrated by the fact that treating zebrafish embryos with $\mathrm{E}_{2}$ or the anti-oestrogen, ICI 164,384 $\left(10^{-8} \mathrm{M}\right.$ for $72 \mathrm{~h}$ starting at $1 \mathrm{~h}$ after fertilization in both cases) did not lead to an increase in ER expression, and did not have any obvious morphological effect (data not shown).

In summary, zfERs can react to oestrogenic compounds in a different way from their mammalian counterparts, including a total lack of transcriptional response to molecules that are powerful activators of mERs. In contrast, ERs present a lack of expression during most of the developmental period in zebrafish. Overall, this does not favour Danio rerio as a general model in which to detect the presence of endocrine disruptors acting on oestrogen receptors. One should therefore be aware that results obtained in zebrafish will be difficult to extrapolate to mammals.

\section{Acknowledgements}

This work was supported by grants from the Association pour la Recherche sur le Cancer, Centre National de la Recherche Scientifique and Ministère de la Recherche et de la Technologie. B H is supported by Hoeschst Marion Roussel funding programme. We are indebted to Farzad Pakdel for the generous gift of reconstituted ER sequences. 


\section{References}

Amores A, Force A, Yan YL, Joly L, Amemiya C, Fritz A, Ho RK, Langeland J, Prince V, Wang YL et al. 1998 Zebrafish hox clusters and vertebrate genome evolution. Science $\mathbf{2 8 2}$ $1711-1714$.

Avioli LV 1999 SERM drugs for the prevention of osteoporosis. Trends in Endocrinology and Metabolism 10 317-319.

Berkenstam A, Glaumann H, Martin M, Gustafsson JA \& Norstedt G 1989 Hormonal regulation of estrogen receptor messenger ribonucleic acid in T47 Dco and MCF-7 breast cancer cells. Molecular Endocrinology 3 22-28.

Brzozowski AM, Pike ACW, Dauter Z, Hubbard RE, Bonn T, Engström O, Öhman L, Greene GL, Gustafsson JA \& Carlquist M 1997 Molecular basis of agonism and antagonism in the oestrogen receptor. Nature 389 753-758.

Couse JF \& Korach KS 1999 Estrogen receptor null mice: what have we learned and where will they lead us? Endocrine Reviewes 20 358-417.

Couse JF, Curtis Hewitt S, Bunch DO, Sar M, Walker WR, Davis BJ \& Korach KS 1999 Postnatal sex reversal of the ovaries in mice lacking estrogen receptors $\alpha$ and $\beta$. Science 2862328 2331.

Delaunay F, Thisse C, Marchand O, Laudet V \& Thisse B 2000 An inherited functional circadian clock in zebrafish embryos. Science $289297-300$

Dupont S, Krust A, Gansmuller A, Dierich A, Chambon P \& Mark M 2000 Effect of single and compound knockouts of estrogen receptors $\alpha(\mathrm{ER} \alpha)$ and $\beta(\mathrm{ER} \beta)$ on mouse reproductive phenotypes. Development 127 4277-4291.

Felsenstein J 1985 Confidence limits on phylogenies: an approach using the bootstrap. Evolution 39 783-791.

Fisher CR, Graves KH, Parlow AF \& Simpson ER 1998 Characterization of mice deficient in aromatase (ArKO) because of targeted disruption of the cyp 19 gene. PNAS 95 6965-6970.

Galtier N, Gouy M \& Gautier C 1996 SEAVIEW and PHYLO_WIN: two graphic tools for sequence alignment and molecular phylogeny. Computer Applications in the Biosciences 12 543-548.

Green S, Walter P, Kumar V, Krust A, Bornert JM, Argos P \& Chambon P 1986 Human estrogen receptor cDNA: sequence, expression and homology to v-erbA. Nature 320 134-139.

Gronemeyer H \& Laudet V 1995 Transcription factors 3: nuclear receptors. In Protein Profile, vol 2, pp 1173-1308. Ed P Sheterline. Liverpool: Academic Press.

Hall JM, Couse JF \& Korach KS 2001 The multifaceted mechanisms of estradiol and estrogen receptor signaling. Fournal of Biological Chemistry 276 36869-36872.

Hawkins MB, Thornton JW, Crews D, Skipper JK, Dotte A \& Thomas P 2000 Identification of a third distinct estrogen receptor and reclassification of estrogen receptors in teleosts. PNAS $\mathbf{9 7}$ 10751-10756

Hou Q \& Gorski J 1993 Estrogen receptor and progesterone receptor genes are expressed differentially in mouse embryos during preimplantation development. PNAS 90 9460-9464.

Jordan VC \& Morrow M 1999 Tamoxifen, raloxifene, and the prevention of breast cancer. Endocrine Reviewes 20 253-278.

Kishida M \& Callard GV 2001 Distinct cytochrome P450 aromatase isoforms in zebrafish (Danio rerio) brain and ovary are differentially programmed and estrogen regulated during early development. Endocrinology 142 740-750.

Krege JH, Hodgin JB, Couse JF, Enmark E, Warner M, Mahler JF, Sar M, Korach KS, Gustafsson J-A \& Smithies O 1998 Generation and reproductive phenotypes of mice lacking estrogen receptor $\beta$. PNAS 95 15677-15682.
Kuiper GGJM, Enmark E, Pelto-Huikko M, Nilsson S \& Gustafsson J-A 1996 Cloning of a novel estrogen receptor expressed in rat prostate and ovary. PNAS 93 5925-5930.

Kuiper GGJM, Carlsson B, Grandien K, Enmark E, Häggblad J, Nilsson S \& Gustafsson J-A 1997 Comparison of the ligand binding specificity and transcript tissue distribution of estrogen receptors $\alpha$ and $\beta$. Endocrinology $138863-870$.

Laudet V 1997 Evolution of the nuclear receptor superfamily: early diversification from an ancestral orphan receptor. Fournal of Molecular Endocrinology 19 207-226.

Lemmen JG, Broekhof JLM, Kuiper GGJM, Gustafsson J-A, van der Saag PT \& van der Burg B 1999 Expression of estrogen receptor alpha and beta during mouse embryogenesis. Mechanisms of Development 81 163-167.

Lubahn DB, Moyer JS, Golding TS, Couse JF, Korach KS \& Smithies O 1993 Alteration of the reproductive function but not prenatal sexual development after insertional disruption of the mouse estrogen receptor gene. PNAS $\mathbf{9 0}$ $11162-11166$

McDonnell 1999 The molecular pharmacology of SERMs. Trends in Endocrinology and Metabolism 10 301-311.

Mangelsdorf DJ, Thummel C, Beato M, Herrlich P, Schutz G, Umesono K, Blumberg B, Kastner P, Mark M, Chambon P et al. 1995 The nuclear receptor superfamily: the second decade. Cell 83 835-839.

Paech K, Webb P, Kuiper GGJM, Nilsson S, Gustafsson J-A, Kushner PJ \& Scanlan TS 1997 Differential ligand activation of estrogen receptors ER $\alpha$ and ER $\beta$ at AP1 sites. Science 277 $1508-1510$

Pakdel F, Le Guellec C, Vaillant C, Le Roux MG \& Valotaire Y 1989 Identification and estrogen induction of two estrogen receptors (ER) messenger ribonucleic acids in the rainbow trout liver: sequence homology with other ERs. Molecular Endocrinology $\mathbf{3}$ 44-51.

Peterson RT, Link BA, Dowling JE \& Schreiber SL 2000 Small molecule developmental screens reveal the logic and timing of vertebrate development. PNAS 97 12965-12969.

Robinson-Rechavi M, Marchand O, Escriva H, Bardet PL, Zelus D, Hughes S \& Laudet V $2001 a$ Euteleost fish genomes are characterized by expansion of gene families. Genome Research $\mathbf{1 1}$ 781-788.

Robinson-Rechavi M, Marchand O, Escriva H \& Laudet V $2001 b$ An ancestral whole-genome duplication may not have been responsible for the abundance of duplicated fish genes. Current Biology 11 R458-R459.

Saitou N \& Nei M 1987 The neighbor-joining method: a new method for reconstructing phylogenetic trees. Molecular Biology and Evolution 4 406-425.

Saville B, Wormke M, Wang F, Nguyen T, Enmark E, Kuiper GGKM, Gustafsson J-A \& Safe S 2000 Ligand-, cell-, and estrogen receptor subtype $(\alpha / \beta)$-dependent activation at GC-rich (Spl) promoter elements. Fournal of Biological Chemistry 275 5379-5387.

Thomson JD, Higgins DG \& Gibson TJ 1994 CLUSTAL W: improving the sensitivity of progressive multiple sequence alignment through sequence weighting, position-specific gap penalties and weight matrix choice. Nucleic Acids Research 22 $4673-4680$.

Tremblay GB, Tremblay A, Copeland NG, Gilbert DJ, Jenkins NA, Labrie F \& Giguere V 1997 Cloning, chromosomal localization, and functional analysis of the murine estrogen receptor $\beta$. Molecular Endocrinology 11 353-365.

Vanacker JM, Pettersson K, Gustafsson JA \& Laudet V 1999 Transcriptional targets shared by estrogen receptor-related receptors (ERRs) and estrogen receptor (ER) alpha, but not by ERbeta. EMBO fournal 18 4270-4279. 
Watanabe T, Inoue S, Ogawa S, Ishii Y, Hiroi H, Ikeda K, Orimo A \& Muramatsu M 1997 Agonistic effect of tamoxifen is dependent on cell type, ERE-promoter context, and estrogen receptor subtype: functional difference between estrogen receptors- $\alpha$ and $\beta$. Biochemical and Biophysical Research Communications 236 140-145.

Weihua Z, Saji S, Mäkinen S, Cheng G, Jensen EV, Warner M \& Gustafsson J-A 2000 Estrogen receptor (ER) $\beta$, a modulator of $\mathrm{ER} \alpha$ in the uterus. PNAS 97 5936-5941.
Weihua Z, Mäkelä S, Andersson LC, Salmi S, Saji S, Webster JI, Jensen EV, Nilsson S, Warner M \& Gustafsson J-A 2001 A role for estrogen receptor $\beta$ in the regulation of growth of the ventral prostate. PNAS 98 6330-6335.

Received in final form 23 January 2002

Accepted 30 January 2002 